\title{
Meningkatkan Perkembangan Sosial Anak Usia Dini melalui Metode Proyek
}

\section{Hillia Izza}

Pendidikan Islam Anak Usia Dini, Universitas Islam Negeri Sultan Thaha Saifuddin Jambi DOI: $\underline{10.31004 / \text { obsesi.v4i2.483 }}$

\begin{abstract}
Abstrak
Penelitian ini bertujuan untuk meningkatkan perkembangan sosial melalui metode proyek. Sampel pada penelitian ini adalah anak kelompok B di Taman Kanak-kanak Aisyiyah Bustanul Athfal IV Kota Jambi yang berjumlah 15 anak yang terdiri dari 9 laki-laki dan 6 Perempuan. Penelitian ini termasuk penelitian tindakan kelas dengan menggunakan model Kemmis dan Mc.Taggart yang terdiri dari 4 tahap (perencanaan, tindakan, observasi dan refleksi). Teknik pengumpulan data melalui observasi dan dokumentasi. Teknik analisis data menggunakan deskriptif analitik. Hasil penelitian menunjukkan adanya peningkatan perkembangan sosial dengan menggunakan metode proyek selama dua siklus yang dikategorikan berkembang sangat baik (BSB). Kesimpulan pada penelitian ini adalah penggunaan metode proyek dapat meningkatkan perkembangan sosial anak.
\end{abstract}

Kata kunci: anak usia dini; perkembangan sosial; metode proyek

\begin{abstract}
This research aims to enchance social development throught project methods. The sample in this study were children of group B in Aisyiyah Bustanul Athfal IV Kindergarten in Jambi City with total of 15 children consisting of 9 boys and 6 girls. This research includes classroom action research usin Kemmis and Mc.Taggart models cycles consisting of 4 stages (planning, action, observation, and reflection). Data collection techniques through observation and documentatio. Data analysis techniques using descriptive analitic. The result showed an increase in social development using the project method for two cycles that were categorized as developing very well (BSB). The conclusion of this study is the use of project methods can improve children's social development.
\end{abstract}

Keywords: earlychildhood; social development; project methods

$\triangle$ Corresponding author:

Email Address : hilliaizza@gmail.com (Jambi, Indonesia)

Received 27 February 2020, Accepted 10 March 2020, Published 11 March 2020 


\section{PENDAHULUAN}

Anak usia dini merupakan masa paling optimal untuk berkembang. Perkembangan anak pada tahun-tahun pertama sangat penting dan akan menentukan perkembangan anak selanjutnya. Anak usia dini adalah anak-anak yang memiliki rasa ingin tahu besar dan senang berpetualang dengan mengeksplor lingkungan sekitar anak. Karakteristik seperti itu perlu dipahami pendidik sehingga dapat menyediakan lingkungan belajar yang sesuai untuk mengembangkan potensi yang dimiliki anak. Sesuai yang di ungkapkan oleh (Perdina, Safrina, and Sumadi 2019) yang menyebutkan bahwa karakteristik anak usia dini tidak terlepas dari bermain yang merupakan kegiatan yang menyenangkan dan dapat merangsang berbagai kemampuan anak yang harus dikembangkan anak usia dini.

Menteri Pendidikan dan Kebudayaan Republik Indonesia Nomor 146 Tahun 2014 tentang Kurikulum 2013 Pendidikan Anak Usia Dini pasal 1, Pendidikan Anak Usia Dini yang selanjutnya disingkat PAUD, merupakan suatu upaya pembinaan yang ditujukan kepada anak sejak lahir sampai dengan usia 6 (enam) tahun yang dilakukan melalui pemberian rangsangan pendidikan untuk membantu pertumbuhan dan perkembangan jasmani dan rohani agar anak memiliki kesiapan dalam memasuki pendidikan lebih lanjut (Kementrian Pendidikan Nasional 2010:3). Anak yang telah memasuki dunia pendidikan khususnya PAUD akan berinteraksi dengan lingkungan dimana mereka berada, berinteraksi dengan teman sebayanya maupun dengan orang dewasa. Di lingkungan sosial ini anak memperoleh kemampuan berperilaku, mampu bersosialisasi, dan dapat menyesuaikan diri dengan teman kelompok sebaya serta mereka dapat belajar bekerjasama dalam kegiatan bermain. Melalui interaksi sosial anak akan memperoleh pengalaman sehingga dapat membangun pengetahuannya. Hal tersebut sesuai pendapat Vigotsky menyatakan bahwa anak membangun pengetahuannya melalui interaksi sosial dan pembelajaran dengan orang dewasa (Masitoh, Ocih Setiasih 2005:72)

Perkembangan sosial merupakan proses belajar untuk menyesuaikan diri terhadap norma-norma kelompok, moral dan tradisi, melebur jadi satu kesatuan dan saling berkomunikasi dan kerja sama. Perkembangan sosial anak yang sehat bergantung pada pembelajaran dan standar internalisasi prilaku sosial serta dalam mentransfer dan menerapkan standar ini dalam berprilaku anak diberbagai lingkungan dan situasi (Poerwati and Cahaya 2018). Proses sosial sangat diperlukan dalam belajar kelompok karena anak berhubungan dengan teman sebaya sehingga anak harus dapat mengontrol emosinya agar tercipta suasana kondusif dalam belajar (Ananda and Fadhilaturrahmi 2018). Sikap sosial pada anak terlihat pada aktivitas dan kegiatan anak dalam bekerjasama baik itu dengan orang lain, teman sebaya dan guru (Marlina 2014). Untuk bersosialisasi dengan baik anakanak harus merasa nyaman dengan orang dan kegiatan sosialnya.

Kurikulum 2013 No. 137 Tahun 2013 tentang Standar Pendidikan Anak Usia Dini, terdapat beberapa Tingkat Pencapaian Perkembangan (TPP) yang berkaitan dengan perkembangan sosial anak. Tingkat Pencapaian Perkembangan tersebut diantaranya memperlihatkan kemampuan diri untuk menyesuaikan dengan situasi, mengenal perasaan sendiri dan mengelolanya secara wajar, mentaati aturan kelas, bertanggung jawab atas perilakunya untuk kebaikan diri sendiri dan orang lain serta berperilaku prososial (Kementrian Pendidikan Nasional 2010). 


\section{Tabel 1. Indikator Perkembangan Sosial Anak Usia Dini}

\begin{tabular}{|c|c|}
\hline Lingkup Perkembangan & $\begin{array}{l}\text { Indikator Tingkat Pencapaian Perkembangan Anak Usia } \\
\text { 5-6 Tahun }\end{array}$ \\
\hline $\begin{array}{l}\text { Sosial } \\
\text { Kesadaran diri }\end{array}$ & 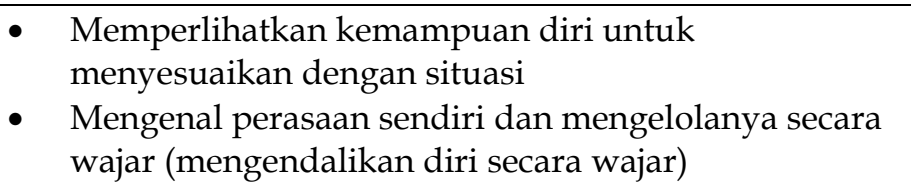 \\
\hline $\begin{array}{l}\text { Rasa tanggung jawab untuk diri } \\
\text { sendiri dan orang lain }\end{array}$ & $\begin{array}{l}\text { - } \quad \text { Mentaati aturan kelas (kegiatan, aturan) } \\
\text { Bertanggung jawab atas perilakunya untuk kebaikan } \\
\text { diri sendiri dan orang lain }\end{array}$ \\
\hline Perilaku Prososial & $\begin{array}{l}\text { - } \quad \text { Bermain dengan teman sebaya } \\
\text { - } \quad \text { Mengetahui perasaan temannya dan merespon secara } \\
\text { - } \quad \text { Menghargai hak/ pendapat/ karya orang lain } \\
\text { - } \quad \text { Bersikap kooperatif dengan teman }\end{array}$ \\
\hline
\end{tabular}

Berdasarkan hasil pengamatan yang dilakukan pada tanggal 1 Agustus 2019 pada kelompok B di Taman Kanak-kanak Aisyiyah Bustanul Athfal IV terdapat 15 anak yang perkembangan sosial anak harus ditingkatkan. Hal ini terlihat saat melakukan pengamatan anak belum bisa memperlihatkan kemampuannya. Saat guru memberikan suatu permainan yang harus diselesaikan secara bersama, anak belum bisa menyesuaikan situasi dengan teman yang lain. Peneliti juga mengamati terdapat anak yang lebih senang bermain sendiri dibandingkan bermain dengan teman sebayanya, tidak memperdulikan apa yang sedang dialami teman yang lain. Selain itu peneliti juga mengamati anak ketika bermain anak belum bisa mentaati aturan, anak masih ingin menguasai mainan dalam kelas dan belum bisa berbagi mainan dengan teman yang lain akibatnya sering terjadi perebutan mainan. Anak masih sulit dalam bekerjasama. Hal ini terlihat ketika guru mengintruksikan anak untuk membangun sebuah bangunan dari balok secara bersama atau kelompok, anak masih mengalami kesulitan dalam melakukan kegiatan-kegiatan kelompok yang membutuhkan partisipasi semua anak dan sikap egosentris anak masih tinggi.

Untuk meningkatkan perkembangan sosial anak di Taman kanak-kanak Aisyiyah Bustanul Athfal IV ini guru dapat menggunakan berbagai metode pembelajaran. Metode pembelajaran di Taman Kanak-Kanak diantaranya adalah metode bermain, karyawisata, bercakap-cakap, demontrasi, proyek, bercerita, dan pemberian tugas. Diantara metodemetode tersebut metode yang memberikan kesempatan kepada anak untuk dapat melaksanakan tugas kelompok, anak dapat bekerjasama dengan teman, anak mau bermain dengan teman, dan anak dapat mentaati aturan diantaranya dengan menggunakan metode proyek (Mursid 2015:28). Menurut (Hamidah 2017) metode proyek diasumsikan mampu membantu penanaman karakter yang baik dan berguna bagi masa yang akan datang seperti mengenal aturan, rasa ingin tahu, kemandirian dan bagaimana mereka menyesuaikan diri dengan lingkungannya. Keunggulan dari metode proyek ini diantaranya anak terlibat dalam suatu kegiatan bersama yang memacu anak dengan masalah sosial dan anak dapat berinteraksi dengan temannya sehingga perkembangan sosial anak dapat meningkat (Ni Putu Suarningsih Eka Putri, Luh Ayu Tirtayani 2018). Semakin banyak kesempatan yang anak miliki untuk melakukan suatu hal bersama-sama, semakin cepat anak belajar melakukannya dengan bekerjasama (Fauziddin 2016).

Dengan demikian dapat diartikan bahwa metode proyek ini menjadi salah satu cara untuk memecahkan permasalahan terkait perkembangan sosial anak. Penerapan metode proyek ini diasumsikan dapat membiasakan anak untuk berinteraksi dengan sesamanya, serta membiasakan anak untuk memilih, merancang dan memimpin pekerjaan dalam mencapai tujuan bersama. Kemampuan yang dapat dikembangkan melalui penggunaan metode proyek salah satunya adalah kemampuan bersosialisasi dan kemampun untuk bekerjasama (Masitoh, Ocih Setiasih 2005) 
Berdasarkan masalah yang telah dikemukakan diatas, maka peneliti sangat tertarik melakukan penelitian di Taman Kanak-kanak Aisyiyah Bustanul Athfal IV Kota Jambi untuk meningkatkan Perkembangan Sosial Anak Usia Dini dengan Penerapan Metode Proyek.

\section{METODOLOGI}

Penelitian ini merupakan jenis penelitian tindakan kelas (Classroom Action Research). Penelitian tindakan kelas adalah suatu pencermatan terhadap kegiatan belajar berupa sebuah tindakan, yang sengaja dimunculkan dan terjadi dalam kelas secara bersama tindakan tersebut diberikan oleh guru atau dengan arahan guru yang dilakukan oleh siswa (Suharsimi arikunto 2014:3)

Sampel pada penelitian ini adalah anak kelompok B sebanyak 15 anak yang terdiri dari 9 laki-laki dan 6 perempuan. Teknik pengambilan data pada penelitian ini adalah lembar observasi. Teknik analisis data menggunakan deskriptif analisis. Penelitian tindakan kelas ini menggunakan model kemmis dan Taggart. Dalam model ini terdapat empat komponen yaitu Perencanaan, pelaksanaan, pengamatan, dan refleksi (Johni Dimyati 2013:124)

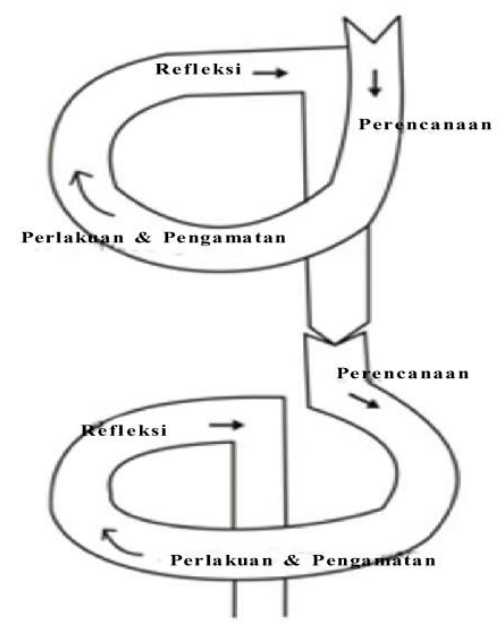

\section{Gambar 1. model spiral Kammis dan Taggart}

Selnjutnya Data yang diperoleh selama proses pembelajaran dianalisis menggunakan teknik persentase meningkatkan perkembangan sosial anak dengan menggunakan rumus yang di kemukakan oleh (Suryono 2014:16) sebagai berikut:

$$
\mathrm{P}=\frac{\mathrm{F} \times 100}{\mathrm{~N}}
$$

Keterangan:

$\mathrm{P} \quad=$ Hasil persentase

$\mathrm{F} \quad=$ Jumlah siswa yang tuntas

$\mathrm{N} \quad=$ Jumlah frekuensi / banyak individu

$100 \%=$ Bilangan tetap

Aktivitas sosial anak dikatakan meningkat jika presentase hasil kegiatan anak meningkat dari hasil pengamatan berikutnya. Peningkatan aktivitas anak ditentukan berdasarkan kriteria sebagai berikut:

$75 \%-100 \%$ : Berkembang Sangat Baik (BSB)

$50 \%-75 \%$ : Berkembang Sesuai Harapan (BSH)

$25 \%-50 \%$ : Mulai Berkembang (MB)

$0 \%-25 \% \quad$ : Belum Berkembang (BB) 


\section{HASIL DAN PEMBAHASAN Prasiklus}

Langkah awal yang dilakukan peneliti sebelum melakukan penelitian tindakan kelas yaitu melalui pengamatan. Peneliti melakukan pengamatan terhadap permasalahan yang terjadi di Taman Kanak-kanak Aisyiyah Bustanul Athfal IV Kota Jambi yaitu aspek Perkembangan Sosial yang terdiri dari Memperlihatkan kemampuan diri untuk menyesuaikan dengan situasi, Mengenal perasaan sendiri dan mengelolanya secara wajar (mengendalikan diri secara wajar), Mentaati aturan kelas (kegiatan, aturan), Bertanggung jawab atas perilakunya untuk kebaikan diri sendiri dan orang lain, Bermain dengan teman sebaya, Mengetahui perasaan temannya dan merespon secara wajar, Menghargai hak/ pendapat/ karya orang lain dan Bersikap kooperatif dengan teman.

Guru melakukan tanya jawab tentang diri sendiri. Kemudian guru menjelaskan kegiatan proyek yang akan dilakukan. Pada pelaksanaan kegiatan pembelajaran tersebut peneliti melakukan pengematan saat anak melakukan kegiatan proyek sesuai dengan yang telah dijelaskan dan diperintahkan oleh guru. Pada saat anak melakukan kegiatan proyek tersebut ditemukannya beberapa anak yang mempunyai perkembangan sosial berada pada kategori kurang hal ini terlihatbahwa anak lebih suka bermain sendiri dari pada bermain dengan kawan yang lain. rasa tanggung jawab anak juga kurang serta perilaku prosial anak juga dikategorikan kurang. Untuk itu peneliti mencoba untuk meningkatkan perkembangan sosial anak usia dini khusus nya di Taman Kanak-kanak Aisyiyah Bustanul Athfal IV Kota Jambi melalui metode proyek. Dengan menggunakan metode proyek peneliti berharap perkembangan sosial anak usia dini dapat berkembang sesuai dengan tahap perkembangan dan umurnya, seperti yang telah peneliti jelaskan dipembahasan. Hasil penelitian dapat di ukur melalui tingkat pencapaian perkembangan dengan indikator yang telah ditentukan pada perkembangan sosial Kelompok B. peneliti berharap perkembangan sosial anak usia dini di Taman Kanak-kanak Aisyiyah Bustanul Athfal IV Kota Jambi dapat di tingkatkan.

Tabel 1. Hasil Observasi Perkembangan sosial Prasiklus

\begin{tabular}{|c|c|c|c|}
\hline No & Aspek penilaian & $\begin{array}{l}\text { Rata-rata Data } \\
\text { Prasiklus }\end{array}$ & Kategori \\
\hline 1. & $\begin{array}{l}\text { Memperlihatkan kemampuan } \\
\text { menyesuaikan dengan situasi }\end{array}$ & $31,6 \%$ & MB \\
\hline 2. & $\begin{array}{l}\text { Mengenal perasaan sendiri dan mengelolanya } \\
\text { secara wajar (mengendalikan diri secara wajar) }\end{array}$ & $33,3 \%$ & MB \\
\hline 3. & Mentaati aturan kelas (kegiatan, aturan) & $35 \%$ & MB \\
\hline 4. & $\begin{array}{l}\text { Bertanggung jawab atas perilakunya untuk } \\
\text { kebaikan diri sendiri dan orang lain }\end{array}$ & $28,3 \%$ & MB \\
\hline 5. & Bermain dengan teman sebaya & $40 \%$ & MB \\
\hline 6. & $\begin{array}{l}\text { Mengetahui perasaan temannya dan merespon } \\
\text { secara wajar }\end{array}$ & $33,3 \%$ & MB \\
\hline 7. & Menghargai hak/ pendapat/ karya orang lain & $33,3 \%$ & MB \\
\hline & Bersikap kooperatif dengan teman. & $33,3 \%$ & MB \\
\hline \multicolumn{2}{|c|}{ Rata-rata indikator keberhasilan kelas } & $33,5 \%$ & MB \\
\hline
\end{tabular}

Dari beberapa indikator diatas, pada indikator Memperlihatkan kemampuan diri untuk menyesuaikan dengan situasi persentasenya 31,6\%. Pada indikator Mengenal perasaan sendiri dan mengelolanya secara wajar (mengendalikan diri secara wajar) persentasenya 33,3\%. Pada Indikator Mentaati aturan kelas (kegiatan, aturan) persentasenya $35 \%$. Pada indikator Bertanggung jawab atas perilakunya untuk kebaikan diri sendiri dan orang lain persentasenya $28,3 \%$. Pada indikator Bermain dengan teman sebaya persentasenya $40 \%$. Pada indikator Mengetahui perasaan temannya dan merespon secara wajar persentasenya 33,3\%. Pada indikator Menghargai hak/ pendapat/ karya orang 
lain persentasenya 33,3\%. Pada indikator Bersikap kooperatif dengan teman persentasenya $33,3 \%$. Adapun hasil rata-rata keberhasilan kelas dalam perkembangan sosial prasiklus ini adalah 33,5\%. Dari data hasil observasi Prasiklus dapat diperjelas melalui grafik dibawah ini:

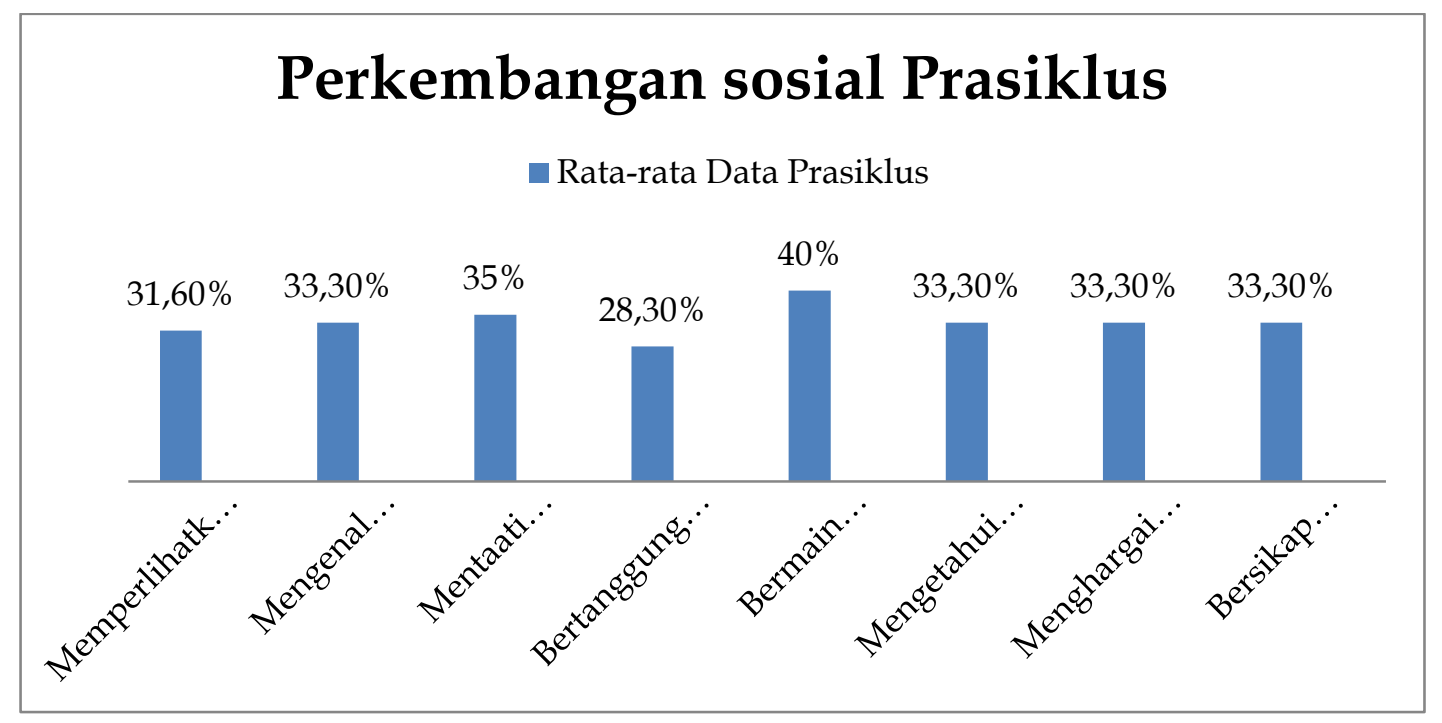

\section{Gambar: Grafik Persentase Perkembangan Sosial Prasiklus}

Berdasarkan grafik perkembangan sosial Prasiklus terlihat dari 8 aspek penilaian masih berada pada kategori Mulai berkembang (MB) dengan rentang persentase 28,30\%$40 \%$, oleh karena itu peneliti akan melakukan tindakan dengan menggunakan metode proyek untuk meningkatkan perkembangan sosial.

\section{Siklus I}

Tindakan Pada Siklus I dilaksanakan sebanyak tiga kali pertemuan Pembelajaran dilakukan selama 2 jam pelajaran ( 2x 60 menit) yang dimulai dari pukul 7.30 WIB. Siklus ini menggunakan empat tahapan yaitu perancanaan, pelaksanaan, observasi dan refleksi. Hasil refleksi ini dijadikan dasar untuk menentukan tindakan perbaikan pada siklus berikutnya.

Setiap pertemuan anak mengerjakan proyek secara berkelompok, proyek pada siklus 1 yaitu membuat berbagai macam bentuk bangunan dari balok. sebelumnya guru dan peneliti telah mempersiapakan rancangan kegiatan yang akan dilaksanakan.

Tabel 2. Hasil Peningkatan Perkembangan Sosial Siklus 1

\begin{tabular}{|c|c|c|c|c|c|}
\hline \multirow[t]{2}{*}{ No } & \multirow[t]{2}{*}{ Aspek Penilaian } & \multicolumn{3}{|c|}{ Siklus 1} & \multirow[t]{2}{*}{ Kategor } \\
\hline & & $\overline{1}$ & 2 & 3 & \\
\hline 1. & $\begin{array}{l}\text { Memperlihatkan kemampuan diri untuk } \\
\text { menyesuaikan dengan situasi }\end{array}$ & $31,6 \%$ & $38,3 \%$ & $48,3 \%$ & MB \\
\hline 2. & $\begin{array}{l}\text { Mengenal perasaan sendiri dan mengelolanya } \\
\text { secara wajar (mengendalikan diri secara wajar) }\end{array}$ & $35 \%$ & $38,3 \%$ & $43,3 \%$ & MB \\
\hline 3. & Mentaati aturan kelas (kegiatan, aturan) & $45 \%$ & $48,3 \%$ & $53,3 \%$ & BSH \\
\hline 4. & $\begin{array}{l}\text { Bertanggung jawab atas perilakunya untuk } \\
\text { kebaikan diri sendiri dan orang lain }\end{array}$ & $33,3 \%$ & $33,3 \%$ & $40 \%$ & MB \\
\hline 5. & Bermain dengan teman sebaya & $40 \%$ & $43,3 \%$ & $53,3 \%$ & BSH \\
\hline 6. & $\begin{array}{l}\text { Mengetahui perasaan temannya dan merespon } \\
\text { secara wajar }\end{array}$ & $33,3 \%$ & $36,6 \%$ & $43,4 \%$ & MB \\
\hline 7. & Menghargai hak/ pendapat/ karya orang lain & $33,3 \%$ & $33,3 \%$ & $38,3 \%$ & MB \\
\hline 8. & Bersikap kooperatif dengan teman. & $33,3 \%$ & $36,6 \%$ & $40 \%$ & MB \\
\hline & Indikator Keberhasilan Kelas & $35,6 \%$ & $38,5 \%$ & $44,9 \%$ & MB \\
\hline
\end{tabular}


DOI: 10.31004/obsesi.v4i2.483

Berdasarkan tabel pengamatan siklus 1 dapat dilihat perkembangan sosial anak belum berkembang secara optimal, dapat diketahui dari aspek Memperlihatkan kemampuan diri untuk menyesuaikan dengan situasi dengan persentase $31,6 \%$ pada pertemuan ke-1 $38,3 \%$ pada pertemuan ke-2 dan 48,3\% pada pertemuanke-3, Mengenal perasaan sendiri dan mengelolanya secara wajar (mengendalikan diri secara wajar dengan persentase $35 \%$ pada pertemuan ke-1 38,3\% pada pertemuan ke-2 dan 43,3\% pada pertemuan ke-3, Mentaati aturan kelas (kegiatan, aturan) dengan persentase 45\% pada pertemuan ke-1 48,3\% pada pertemuan ke-2 dan 53,3\% pada pertemuan ke-3, Bertanggung jawab atas perilakunya untuk kebaikan diri sendiri dan orang lain dengan persentase 33,3\% pada pertemuan ke-1 tidak mengalami penigkatan pada pertemuan ke-2 dengan 33,3\% dan $40 \%$ pada pertemuan ke-3, Bermain dengan teman sebaya dengan persentase $40 \%$ pada pertemuan ke- $143,3 \%$ pada pertemuan ke-2 dan 53,3\% pada pertemuan ke-3, Mengetahui perasaan temannya dan merespon secara wajar dengan persentase 33,3\% pada pertemuan ke-1 33,3\% pada pertemuan ke-2 dan 43,4 pada pertemuan ke-3, Menghargai hak/ pendapat/ karya orang lain dengan persentase $33,3 \%$ pada pertemuan ke-1 tidak mengalami peningkatan pada pertemun ke-2 dengan 33,3\% dan 38,3\% pada pertemuan ke-3, Bersikap kooperatif dengan teman dengan persentase $33,3 \%$ pada pertemuan ke-1 36,6\% pada pertemuan ke-2 dan $40 \%$ pada pertemuan ke-3. Hasil tersebut masih berada pada kategori Mulai Berkembang (MB), dari data tabel berikut dapat diperjelas melalui grafik dibawah ini.

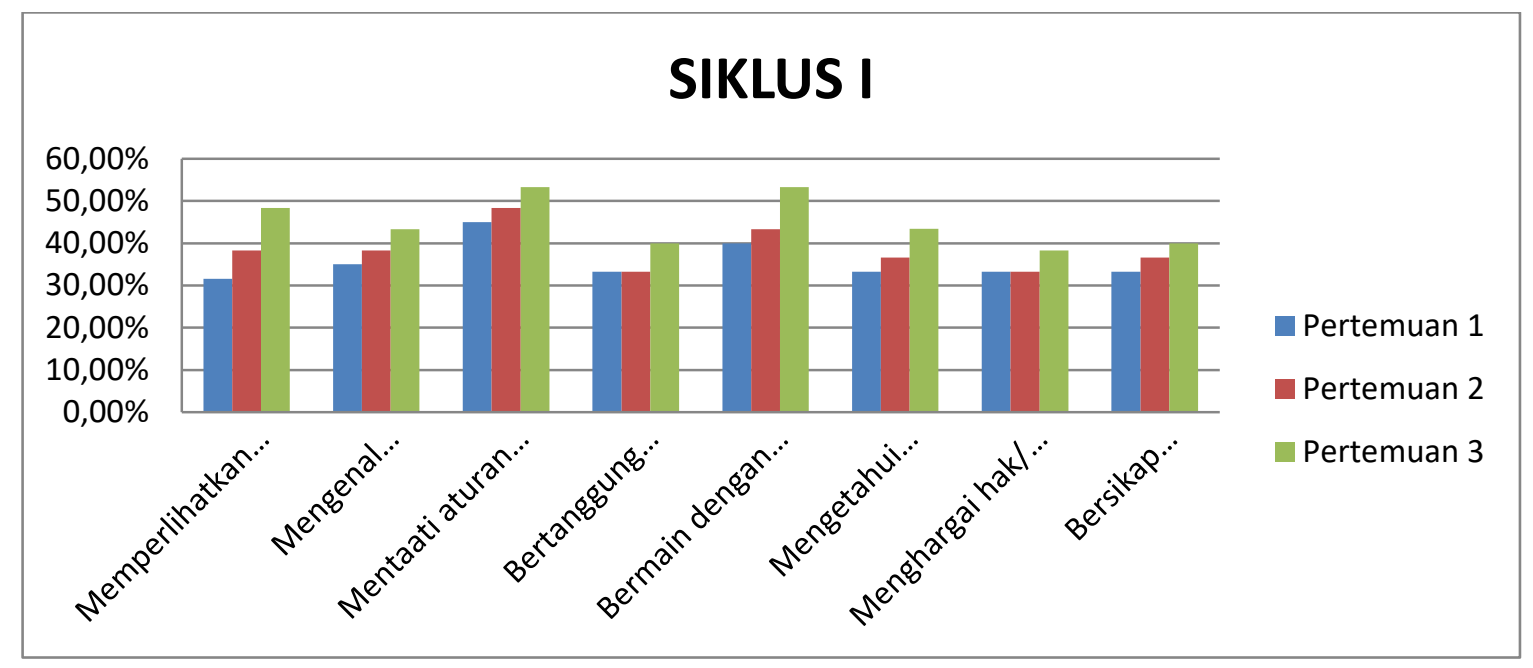

\section{Gambar : Grafik Persentase Peningkatan Perkembangan Sosial Anak Siklus I}

Berdasarkan grafik peningkatan perkembangan sosial anak pada siklus I terlihat dari ke delapan aspek penilaian peningkatan berada pada pertemuan ke tiga, namun masih berada pada kategori mulai berkembang untuk itu indikator tersebut harus ditingkatkan dan dilanjutkan pada siklus II.

Berdasarkan hasil refleksi yang dilakukan peneliti dan guru pada akhir siklus I, Refleksi berupa koreksi terhadap tindakan yang telah dilaksanakan ini dilakukan untuk mengetahui kekurangan yang ada pada siklus I. Walaupun terdapat peningkatan pada siklus I namun jumlahnya masih dibawah $75 \%$ dari jumlah anak. Adapun permasalahan yang muncul pada siklus I ditemukan bahwa 1) Peneliti kurang mengkondisikan peserta didik sehingga kegiatan menjadi sedikit kurang terkontrol 2) Masih banyak anak yang masih ragu dalam melakukan kegiatan 3) Pemahaman sosial masih kurang saat mengtasi masalah atau konflik karena kurangnya pengarahan dari guru 4) Peneliti harus lebih kreatif dan menyenangkan dalam penyampaian kegiatan kepada peserta didik sehingga peserta didik lebih antusias dan semangat dalam mengikuti kegiatan pembelajaran. 
Proses pembelajaran pada siklus 1 masih memiliki beberapa kekurangan sehingga perlu dilakukan siklus II. Berdasarkan hasil refleksi di atas maka peneliti melakukan perbaikan pembelajaran pada siklus II. Berikut langkah-langkah perbaikan yang akan dilaksanakan pada siklus II, 1) Peneliti lebih mengkondisikan peserta didik dengan membuat aturan permainan yang telah disepakati diawal sehingga anak dapat tekontrol 2) Peneliti harus lebih meyakinkan dan memberi motivasi kepada peserta dididk agar anak percaya diri dalam melakukan kegiatan 3) Peneliti harus membuat aturan yang disepakati bersama anak agar dapat di terapkan oleh anak 4) Peneliti menyiapkan kegiatan yang lebih menarik minat dan antusis anak dalam bekerja kelompok.

\section{Hasil Perkembangan Sosial Anak pada Siklus II}

Tindakan Pada Siklus II dilaksanakan sebanyak tiga kali pertemuan. Pembelajaran dilakukan selama 2 jam pelajaran ( 2x 60 menit) yang dimulai dari pukul 7.30 WIB. Kegiatan pembelajaran dilaksanakan sesuai RPPH, pada Siklus II anak-anak akan membuat Proyek Ulang tahun dengan kegiatan menghias topi ulang tahun, memompa balon dan menghias kue ulang tahun. Siklus ini menggunakan empat tahapan yaitu perancanaan, pelaksanaan, observasi dan refleksi.

Tabel 2. Hasil Peningkatan Perkembangan Sosial Siklus II

\begin{tabular}{|c|c|c|c|c|c|}
\hline \multirow[t]{2}{*}{ No } & \multirow[t]{2}{*}{ Aspek Penilaian } & \multicolumn{3}{|c|}{ Siklus 2} & \multirow[b]{2}{*}{ Kategori } \\
\hline & & 1 & 2 & 3 & \\
\hline 1. & $\begin{array}{l}\text { Memperlihatkan kemampuan diri untuk } \\
\text { menyesuaikan dengan situasi }\end{array}$ & $58,3 \%$ & $60 \%$ & $83,3 \%$ & BSB \\
\hline 2. & $\begin{array}{l}\text { Mengenal perasaan sendiri dan mengelolanya } \\
\text { secara wajar (mengendalikan diri secara wajar) }\end{array}$ & $55 \%$ & $60 \%$ & $81,6 \%$ & BSB \\
\hline 3. & Mentaati aturan kelas (kegiatan, aturan) & $55 \%$ & $63,3 \%$ & $80 \%$ & BSB \\
\hline 4. & $\begin{array}{l}\text { Bertanggung jawab atas perilakunya untuk } \\
\text { kebaikan diri sendiri dan orang lain }\end{array}$ & $50 \%$ & $65 \%$ & $78,3 \%$ & BSB \\
\hline 5. & Bermain dengan teman sebaya & $53,3 \%$ & $73,3 \%$ & $93,3 \%$ & BSB \\
\hline 6. & $\begin{array}{l}\text { Mengetahui perasaan temannya dan merespon } \\
\text { secara wajar }\end{array}$ & $51,6 \%$ & $55 \%$ & $80 \%$ & BSB \\
\hline 7. & Menghargai hak/ pendapat/ karya orang lain & $50 \%$ & $61,6 \%$ & $70 \%$ & $\mathrm{BSH}$ \\
\hline 8. & Bersikap kooperatif dengan teman. & $51,6 \%$ & $60 \%$ & $86,6 \%$ & BSB \\
\hline & Indikator Keberhasilan Kelas & $53,1 \%$ & $62,2 \%$ & $81,6 \%$ & BSB \\
\hline
\end{tabular}

Berdasarkan tabel pengamatan siklus II dapat dilihat perkembangan sosial anak sudah mengalami peningkatan yang cukup signifikan, dapat diketahui dari aspek Memperlihatkan kemampuan diri untuk menyesuaikan dengan situasi dengan persentase $58,3 \%$ pada pertemuan ke-1 $60 \%$ pada pertemuan ke-2 dan $83,3 \%$ pada pertemuanke-3, Mengenal perasaan sendiri dan mengelolanya secara wajar (mengendalikan diri secara wajar dengan persentase $55 \%$ pada pertemuan ke- $160 \%$ pada pertemuan ke- 2 dan $81,6 \%$ pada pertemuan ke-3, Mentaati aturan kelas (kegiatan, aturan) dengan persentase $55 \%$ pada pertemuan ke-1 63,3\% pada pertemuan ke-2 dan $80 \%$ pada pertemuan ke-3, Bertanggung jawab atas perilakunya untuk kebaikan diri sendiri dan orang lain dengan persentase $50 \%$ pada pertemuan ke- 1 tidak mengalami penigkatan pada pertemuan ke- 2 dengan $65 \%$ dan $78,3 \%$ pada pertemuan ke-3, Bermain dengan teman sebaya dengan persentase $53,3 \%$ pada pertemuan ke-1 73,3\% pada pertemuan ke-2 dan 93,3\% pada pertemuan ke-3, Mengetahui perasaan temannya dan merespon secara wajar dengan persentase $51,6 \%$ pada pertemuan ke- $155 \%$ pada pertemuan ke-2 dan $80 \%$ pada pertemuan ke-3, Menghargai hak/ pendapat/ karya orang lain dengan persentase $50 \%$ pada pertemuan ke-1 mengalami peningkatan pada pertemun ke-2 dengan $61,6 \%$ dan $70 \%$ pada pertemuan ke-3, Bersikap kooperatif dengan teman dengan persentase $51,6 \%$ pada pertemuan ke- $160 \%$ pada pertemuan ke-2 dan 
DOI: $10.31004 /$ obsesi.v4i2.483

$86,6 \%$ pada pertemuan ke-3. Hasil pada siklus II sudah mengalami peningkatan yang cukup signifikan dan sudah berada pada kategori Berkembang Sangat Baik (BSB) dari data tabel berikut dapat diperjelas melalui grafik dibawah ini.

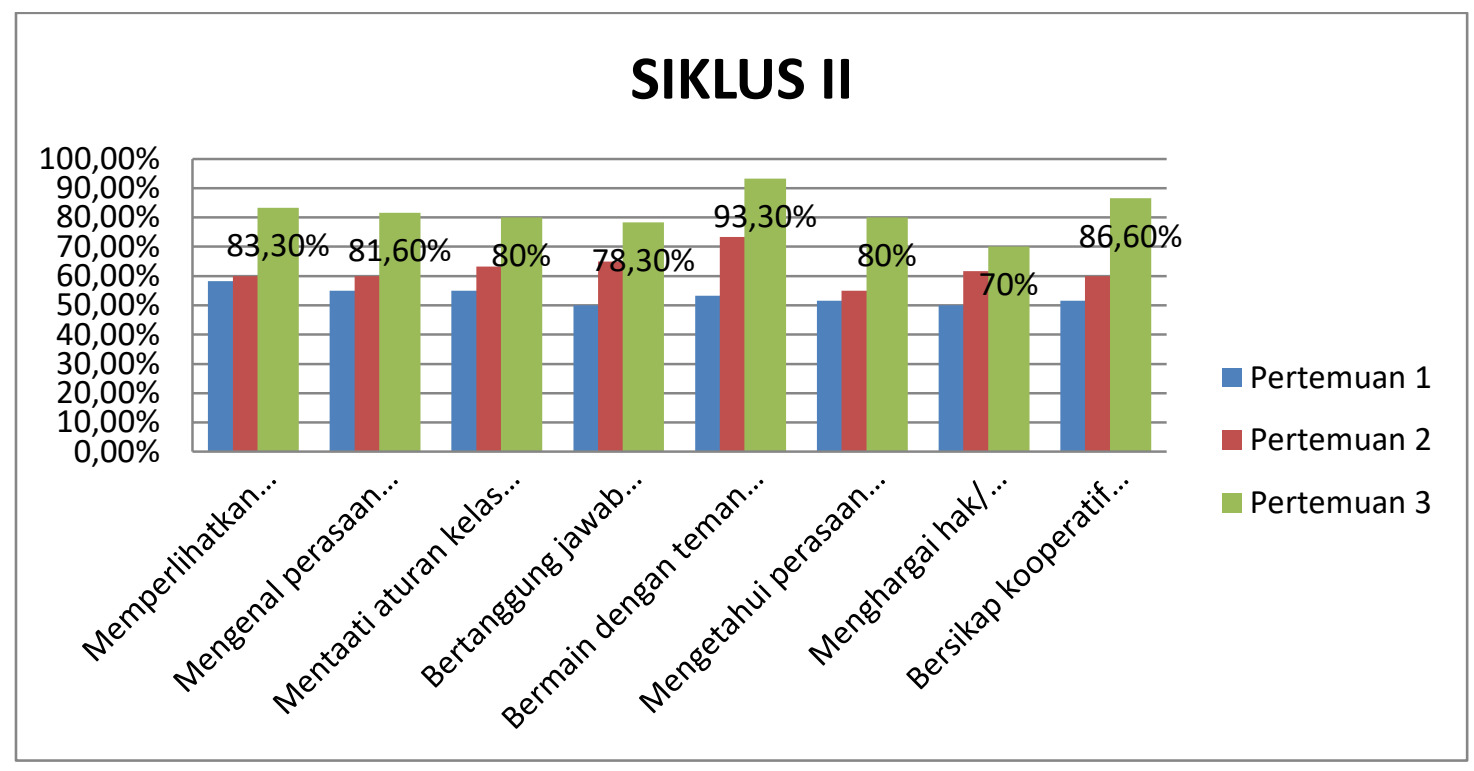

Gambar : Grafik Persentase Perkembangan Sosial anak Siklus II

Pada bagian ini dikemukakan pembahasan mengenai hasil observasi perkembangan sosial anak. Pada kondisi saat prasiklus, peneliti melihat bahwa masih banyak anak yang belum bisa bersosialisasi dengan baik, mengontrol emosi dengan wajar, tidak bisa bekerjasama dengan temannya dan mentaati aturan dalam bermain. Berdasarkan kondisi awal tersebut, terlihat beberapa anak di taman kanak-kanak Aisyiyah Bustanul Athfal IV Kota Jambi mengalami kesulitan dalam bersosialisasi dan bekerjasama dengan temannya. Dampak yang ditimbulkan dari kondisi tersebut adalah perkembangan sosial anak tidak dapat berkembang dengan baik. Kondisi awal saat pra siklus menunjukkan, dari jumlah anak 15 orang yang berada pada kategori mulai berkembang (MB) sebanyak 12 orang sedangkan 3 orang lainnya masih pada tahap belum berkembang (BB). Anak-anak yang berkembang masih harus terus dibantu oleh ibu guru. Dari beberapa indikator diatas, pada indikator Memperlihatkan kemampuan diri untuk menyesuaikan dengan situasi persentasenya 31,6\%. Pada indikator Mengenal perasaan sendiri dan mengelolanya secara wajar (mengendalikan diri secara wajar) persentasenya 33,3\%. Pada Indikator Mentaati aturan kelas (kegiatan, aturan) persentasenya 35\%. Pada indikator Bertanggung jawab atas perilakunya untuk kebaikan diri sendiri dan orang lain persentasenya $28,3 \%$. Pada indikator Bermain dengan teman sebaya persentasenya $40 \%$. Pada indikator Mengetahui perasaan temannya dan merespon secara wajar persentasenya 33,3\%. Pada indikator Menghargai hak/ pendapat/ karya orang lain persentasenya 33,3\%. Pada indikator Bersikap kooperatif dengan teman persentasenya 33,3\%. Adapun hasil rata-rata keberhasilan kelas dalam perkembangan sosial prasiklus ini adalah $33,5 \%$.

Setelah diterapkannya pembelajaran pada siklus I peneliti melakukan kegiatan refleksi dengan guru kelas dan disimpulkan bahwa perlu dilnjutkan pada siklus II karena dalam pelaksanaan pada siklus I masih terdapat beberapa kekurangan dan masih banyak anak yang perkembangan sosialnya masih rendah dari 8 aspek yang dinilai. Pembelajaran yang diterapkan pada siklus I belum sepenuhnya terlaksana dengan baik. Pada siklus II peneliti mengubah pembelajaran lebih menarik dan berkesinambungan, mengubah aturan permainan yang disepakati bersama anak, dan memberi motivasi anak untuk menyelesaikan kegiatannya dengan Reward. terlihat pengingkatan yang cukup signifikan karena guru memberi kesempatan kepada anak untuk berkreasi dengan kegiatan yang menarik dengan 
kelompoknya dan betanggung jawab dengan tugasnya masing-masing didalam kelompok untuk menghias kue, membuat topi ulang tahun dan menghias kelas. Berdasarkan penelitian yang dilakukan oleh (Ananda and Fadhilaturrahmi 2018) mengungkapkan keberhasilan meningkatkan perkembangan sosial emosional dengan permainan kolaboratif ditinjau dari aktivitas guru untuk menciptakan suasana kelas yang kondusif.

Berdasarkan pengamatan peneliti dan guru dapat disimpulkan bahwa penggunaan metode proyek untuk meningkatkan perkembangan sosial anak telah menunjukkan keberhasilan hal itu dapat dilihat dari grafik Prasiklus, Siklus I dan siklus II yang terus mengalami peningkatan serta telah mencapai indikator keberhasilan kelas dengan persentase $81,6 \%$ dengan kategori berkembang sangat baik (BSB).

Pembelajaran pada siklus II telah diadakan perbaikan-perbaikan untuk mencapai indikator. Seperti yang dijelaskan oleh (Fadhilaturrahmi and Ananda 2018) bahwa sebagai upaya perbaikan proses pembelajaran perlu dilakukan fase perbaikan diantaranya fase studi kepustakaan, fase analisis siswa, fase analisis materi, dan fase disign pembelajaran. Adapun perbaikan tersebut antara lain Peneliti mengkondisikan peserta didik dengan membuat aturan permainan yang telah disepakati diawal sehingga anak dapat tekontrol, Peneliti meyakinkan dan memberi motivasi kepada peserta dididk agar anak percaya diri dalam melakukan kegiatan, Peneliti menyiapkan kegiatan yang lebih menarik minat dan antusis anak dalam bekerja kelompok. Melalui perbaikan-perbaikan tersebut pembelajaran pada siklus II dapat mencapai indikator yang telah ditentukan.

Menurut hasil penelitian yang telah dilakukan oleh (Evi Puji Astuti 2016) mengemukakan bahwa metode proyek be kegiatan yang menarik bagi anak dan dapatmengasah kesabaran anak, melatih anak untuk berpartisipasi dalam kegiatan kelompokdan melatih anak dalam berinteraksi dengan teman sebayanya.

Menurut (Nur Hidayah Widyaningrum 2016) metode proyek dapat memberikan stimulasi pada anak untuk meningkatkan kerjasama, berinteraksi dan belajar memecahkan masalah sehari-hari yang dihadapinya. Berdasarkan hasil penelitian yang telah dipaparkan maka dapat disimpulkan perkembangan sosial anak mengalami peningkatan yang signifikan dengan penerapan metode proyek pada pembelajarannya. Hasil yang dicapai pada siklus II menjadi dasar bagi peneliti dan guru untuk menghentikan penelitian ini karena sudah sesuai dengan hipotesis tindakan dan sudah mencapai indikator keberhasilan yang sudah ditentukan.

\section{UCAPAN TERIMAKASIH}

Terima kasih kepada kolaborator yang telah memberi persetujuan dan membantu peneliti selama pengumpulan data. Terima kasih kepada pembimbing yang sudah membantu peneliti dalam menyempurnakan hasil penelitianini. Ucapan terima kasih juga disampaikan kepada tim editor Jurnal Obsesi yang telah memberikan saran, kritik dan rekomendasi untuk perbaikan artikel ini.

\section{SIMPULAN}

Bedasarkan hasil penelitian dapat disimpulkan bahwa perkembangan sosial anak kelompok B Taman Kanak-kanak Aisyiyah Bustanul Athfal IV Kota Jambi dapat di tingkatkan melalui metode proyek. Hal tersebut dapat dilihat dari 1) meningkatnya persentase perkembangan sosial anak dari 8 aspek yang menjadi tolak ukur penilaian 2) Perkembangan sosial anak dari kondisi awal sebelum melakukan tindakan masih pada kategori mulai berkembang (MB), pada siklus I sudah mengalami peningkatan, akan tetapi masih belum mencapai tujuan yang diinginkan, kemudian dilanjutkan tindakan pada siklus II dan mengalami peningkatan yang cukup signifikan hingga mencapai kategori berkembang sangat baik (BSB) 3) Metode proyek memberikan pengaruh yang cukup besar untuk meningkatkan perkembangan sosial anak 4) Langkah-langkah pembelajaran yang 
DOI: 10.31004/obsesi.v4i2.483

dilakukan dalam metode proyek diawali dengan melakukan persiapan diantaranya menyiapkan alat dan bahan yang akan digunakan, membagi anak dalam masing-masing kelompok, membuat aturan permainan yang akan disepakati bersama dan pemberian motivasi kepada anak dengan penguatan (reward). Kegiatan penutup merapikan alat dan bahan yang telah digunakan, mengabungkan seluruh hasil setiap kelompok.

\section{DAFTAR PUSTAKA}

Ananda, Rizki and Fadhilaturrahmi Fadhilaturrahmi. 2018. "Peningkatan Kemampuan Sosial Emosional Melalui Permainan Kolaboratif Pada Anak KB." Jurnal Obsesi: Jurnal Pendidikan Anak Usia Dini 2(1):20-26.

Evi Puji Astuti. 2016. "Peningkatan Keterampilan Sosial Anak Usia 5-6 Tahun Melalui Metode Proyek." Jurnal JPP PAUD UNTIRTA 3(2):80-94.

Fadhilaturrahmi, Fadhilaturrahmi and Rizki Ananda. 2018. "Evaluasi Pembelajaran IPS Berbasis Taksonomi Bloom Dua Dimensi Di Sekolah Dasar." Jurnal Basicedu 1(2):1221.

Fauziddin, Mohammad. 2016. "Peningkatan Kemampuan Kerja Sama Melalui Kegiatan Kerja Kelompok Pada Anak Kelompok A TK Kartika Salo Kabupaten Kampar." Jurnal Obsesi : Jurnal Pendidikan Anak Usia Dini 2(1):29.

Hamidah, Mimin. 2017. "Meningkatkan Nilai - Nilai Karakter Anak Usia Dini Melalui Penerapan Metode Proyek." Tunas Siliwangi 3(1).

Johni Dimyati. 2013. Metodologi Penelitian Pendidikandan Aplikasinya Pada Pendidikan Ana Usia Dini (PAUD). Jakarta: Kencana.

Kementrian Pendidikan Nasional. 2010. Kurikulum Taman Kanak-Kanak, Pedoman Penilaian Di Taman Kanak-Kanak. Jakarta.

Marlina, Serli. 2014. "Peningkatan Sikap Sosial Anak Usia Dini Melalui Permainan Puzzle Puzzle Buah Di Taman Kanak-Kanak Aisyiyah 1 Bukittinggi." Jurnal Ilmiah Ilmu Pendidikan XIV(2):109-14.

Masitoh, Ocih Setiasih, dan Djoehaeniheny. 2005. Pendekatan Belajar Aktif Di Taman KanakKanak. Jakarta.

Mursid. 2015. Pengembangan Pembelajaran PAUD. Bandung: PT. Remaja Rosdakarya.

Ni Putu Suarningsih Eka Putri, Luh Ayu Tirtayani, Ni Nyoman Ganing. 2018. "Pengaruh Metode Proyek Terhadap Kemampuan Sosial Anak Kelompok A Di Ra Al Chusnaniyah Surabaya Tahun Ajaran 2017-2018." Pedagogi: Jurnal Anak Usia Dini Dan Pendidikan Anak Usia Dini 6:303-12.

Nur Hidayah Widyaningrum. 2016. "Meningkatkan Keterampilan Sosial Melalui Metode Proyek." Pendidikan Anak Usia Dini 9:940-51.

Perdina, Siska, Rien Safrina, and Tjipto Sumadi. 2019. "Peningkatan Kemampuan Sosial Melalui Bermain Kartu Estafet Pada Anak Usia Dini." Jurnal Obsesi : Jurnal Pendidikan Anak Usia Dini 3(2):440.

Poerwati, Christiani Endah and I. Made Elia Cahaya. 2018. "Project-Based Drawing Activities in Improving Social-Emotional Skills of Early Childhood." Jurnal Obsesi : Jurnal Pendidikan Anak Usia Dini 2(2):183.

Suharsimi arikunto, suhardjono dan supardi. 2014. Penelitian Tindakan Kelas. Jakarta: Bumi Aksara.

Suryono, Hassan. 2014. Metode Analisis Statistik. Jakarta: Ombak. 